\title{
先天性股関節脱臼の $\mathrm{X}$ 線成績の成長過程における推移
}

\author{
九州大学整形外科 \\ 野口康男 ·福 岡 真二 \\ 杉 岡 洋 一
}

国立別府病院整形外科

井 原 和 彦

\author{
Growth-related Radiographic Changes in Cases of \\ Congenital Dislocation of the Hip \\ by \\ Yasuo Noguchi, Shinji Fukuoka, Yoichi Sugioka \\ and Kazuhiko Ihara \\ Department of Orthopaedic Surgery, \\ Faculty of Medicine, Kyushu University
}

\begin{abstract}
Radiological results of 74 congenitally dislocated hip joints, which had been reduced by the Pavlik harness or manual reduction were assessed using Severin's classification at the ages of 6,10 , and 15 years or later. Although approximately a half of the joints showed a temporary improvement in Severin's grading at the age of 10 years, there was no uniform pattern of growth-related change for classification. The results of this study reconfirmed the importance of follow-up until skeletal maturity.
\end{abstract}

Key words : Congenital dislocation of the hip (先天性股関節脱臼), Radiological result (X 線成績)

先天性股関節脱臼の治療の目的は疼痛の発現しない 関節の獲得とも言える。それでは脱臼の整復を行った 初期治療後，いつまで follow-up すればよいのかを その視点から考えた場合, 治療成績が判明し, かつ追 加治療が不要と判断できるまでと言えるかも知れない.

われわれは以前, 最終的な治療成績を幼児期に X 線像から予測できないかを判別関数分析を用いて検討 したが，その結果は 2 歳から 6 歳の間では, 誤って判 断される確率が最も低かった 6 歳でも $20 \%$ であり， 必ずしも正確な判断はむずかしかっだ).そこで今回 は，幼児期から思春期前後を通じて X 線成績に特有 の変化のパターンがないかを調査することを考えた。

もしあれば予測をより正確にできるし，なければ成長 終了まで経過観察するしかないことになる。

すなわち, 本研究の目的は先天股脱の成長に伴う $\mathrm{X}$ 線成績の推移を分析することであり，さらに整復
の方法による差異の有無も併せて検討した.

\section{対象と方 法}

検討対象症例は, 当科で保存的に整復され 15 歳以 後まで補正手術なしで追跡できた先天性股関節脱臼 67 例 74 関節で, 整復法別の内訳はリーメンビューゲ 儿整復例（以下 $R B$ 例）が 51 関節，徒手整復例（以 下 MR 例）が 23 関節である。最終追跡時年齢は 15 歳から 23 歳, 平均 17.2 歳である.

これらの症例について, 6 歳, 10 歳, および 15 歳 以後の各年齢で, シャープ角と $\mathrm{CE}$ 角の $\mathrm{X}$ 線計測を 行い,またこれらの各年齢で Severin 分類の判定 （表1）を行い，成長に伴う変化をそれぞれ検討した。 また，その推移に整復法による差があるかどうかを知 るために, RB 例と MR 例で比較検討した. 
表 1 Severin 分類
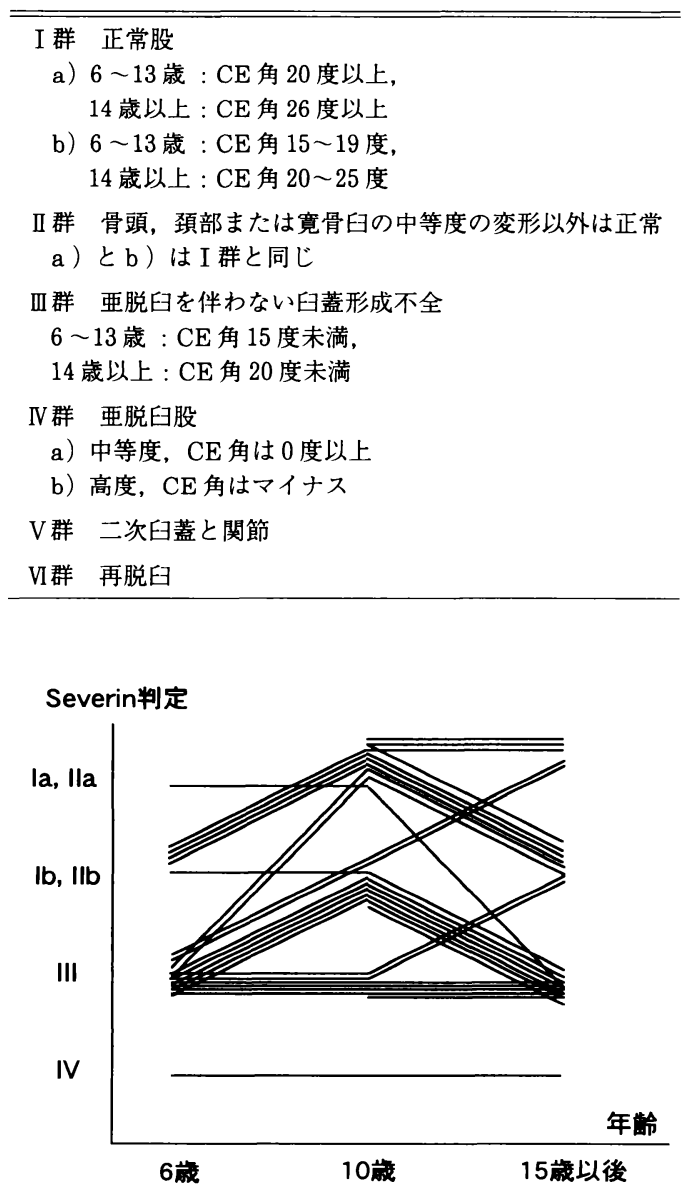

図 1 リーメンビューゲル整復例の成長に伴う Severin 判定の推移.

\section{結果}

全症例の最終的な Severin 判定は, I a 群が 20 関 節， I b 群が 17 関節と I 群だけで約半数を占め, II a 群が 3 関節, II b 群が 2 関節, III群が 27 関節, IV 群 が 5 関節となっていた。整復方法別には，RB 例に良 好な例が多い傾向があった.

成長に伴う Severin 判定の変化をみると, 6 歳から 15 歳では, 改善 $30 \%$, 不変 $60 \%$, 悪化 $10 \%$ で, Severin 判定は不変又は改善が多い傾向である. しかし ながら, 6 歳から 15 歳以後に至る間に, 10 歳の時点 で一時的に Severin 評価が良くなっている症例がみ

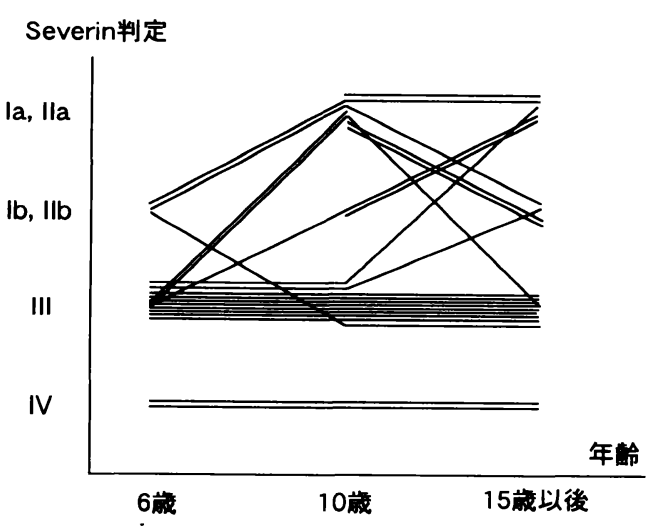

図 2 徒手整復例の成長に伴う Severin 判定の推移.

表 2 成長に伴う $\mathrm{X}$ 線計測値の推移

\begin{tabular}{cccr}
\hline \hline & & Sharp 角 & \multicolumn{1}{c}{ CE 角 } \\
\hline \multirow{2}{*}{6 歳 } & RB 例 & $53.4(2.4)$ & $10.6(6.6)$ \\
& MR 例 & $54.9(3.2)$ & $6.4(6.7)$ \\
\multirow{3}{*}{10 歳 } & RB 例 & $48.5(3.6)$ & $18.3(6.7)$ \\
& MR 例 & $52.0(4.0)$ & $14.4(8.0)$ \\
\multirow{3}{*}{15 歳以後 } & RB 例 & $45.3(3.1)$ & $19.8(6.4)$ \\
& MR 例 & $48.2(4.9)$ & $16.0(10.9)$ \\
\hline & & \multicolumn{2}{c}{ 平均値 (標準偏差) }
\end{tabular}

られることが分かる（図1, 図2）。またこの時のシャー プ角と $\mathrm{CE}$ 角の推移をみると, 6 歳から 10 歳までは 改善が大きく, 10 歳以後の改善は少ない（表 2).

次に, 判定の推移を細かく見ていくと，6歳から 10 歳では全体では半数近くの $45 \%$ が改善を示し，不変 が $52 \%$ ，悪化が $3 \%$ と悪化する症例はほとんどない. 整復法別では RB 例で改善 $59 \%$, 不変 $41 \%$ と改善が 多く, MR 例では改善 $27 \%$, 不変 $67 \%$, 悪化 $6 \%$ と 改善が少ない傾向にある。

この間の X 線計測値の推移をみると（表 2), 両群 とも計測值の改善は見られるものの, RB 例の方が元々 の平均值が優れており, Severin 判定の境界值となる CE 角 15 度または 20 度を越えて，その判定が血群か ら I b 群へ，あるいは I b 群から I a 群へ改善する関 節が多く見られる。

次に 10 歳から 15 歳以後も同様に検討すると, 全症 例では改善 $16 \%$, 不変 $43 \%$ ，悪化 $41 \%$ となり，不変 または悪化がそれぞれ約 $40 \%$ を占め，改善を示す関 
節は少ない. 整復法別では RB 例では改善 $14 \%$, 不 変 $32 \%$, 悪化 $54 \%$ と悪化する関節が多く, その内訳 をみてみると I a 群（または II a 群）から I b 群（ま たは II b 群) へ，あるいは I b 群（または II b 群）か ら III 群へと転落した症例が多い。一方，MR 例では 改善 $19 \%$, 不変 $62 \%$, 悪化 $19 \%$ と不変例が多く, そ の内訳をみると大半は而群のまま推移している症例で ある。

この間の X 線計測值は (表 2), 平均的には MR 例 が不良で, そのため MR 例では評価が向群に留まっ ている.一方, RB 例の方は 14 歳以後の Severin 判 定の境界值となる $\mathrm{CE}$ 角 20 度および 25 度よりわずか に CE 角が下回る症例が多く, CE 角の改善があまり ないため, 評価が悪化する症例が多い.

\section{考察}

先天性股関節脱臼の治療成績の判定によく用いられ るSeverin 分類は, 骨頭の位置（脱臼，亜脱臼の有 無）と変形の有無, および CE 角をもとに判定され, CE 角は 13 歳までと 14 歳以後では異なる值を各群の 境界值として用いている。このことを良く理解すると 今回の結果を分析することが容易となる.

6 歳から 10 歳の推移では, 約半数の症例が改善を 示し, 特に RB 例で改善が多く, MR 例では改善が 少なかった。これは, 両群とも計測値の改善（主に臼 蓋縁の骨化による）は見られるものの，RB例の方が 元々の平均值も優れており, 尚かつ改善も大きいため Severin 判定の CE 角の境界値（15度および 20 度） を越えて判定が良くなる例が多いものと考えられる. 尚, 計測値において見られる両群間の差は臼蓋形成不 全の程度の差がその主因であろう。

10 歳から 15 歳以後では全体では不変と悪化がそれ ぞれ約 $40 \%$ を占め, 整復法別では RB 例で悪化が多 く，I a 群（またはII a 群）から I b 群（または II b 群）へ，あるいはＩb群（またはII b 群）から III群へ 転落した症例が多い。一方，MR 例では而群のまま 不変が多い.これは, $\mathrm{X}$ 線計測値の改善が極めて少 ない（臼蓋の成長の鈍化による）ため, Severin 判定 の分かれ目となる CE 角が 14 歳から厳しくなるため, $\mathrm{RB}$ 例ではこの境界值より良くなることが出来ずに判
定が悪化する症例が多くなり，また MR 例でも境界 値より低いままのため判定が皿群のままに留まったと 考えられる。

成長に伴う Severin 判定の変化についてはいくつ かの報告がこれまでなされているが，そのうち片田 $ら^{2)}$ は股関節脱臼例について 6 歳から 15 歳では改善 $24 \%$ ，不変 $55 \%$ ，悪化 $20 \%$ であったと報告しており， 我々の結果より改善がやや少なく，悪化がやや多いが, 比較的同じような傾向を示している。一方，池田ら は臼蓋形成不全または亜脱臼と診断された症例につい て, 学童期と骨成熟期の Severin 判定の比較を行い, その間に判定は著明に改善し，悪化した症例はなかっ たと報告しており，脱臼ではなく形態的異常が一般に 軽度な臼蓋形成不全や亜脱臼では全く異なる経緯を辿 ることがこれにより明らかである。

いずれにしても，以上のように成長に伴い Severin 判定はある程度似たような経過を示すことが多いが, 必ずしも同じ経過は示さず, その予測はやはり困難と 言わざるを得ない. 従って，X 線像（各種計測值） からの予後の予測は不確実性が伴うことをよく理解し， 補正手術の適応の決定には慎重でなくてはならないし, 成長終了までの経過観察はやはり欠くことが出来ない と考える.

$$
\text { ま と め }
$$

(1)保存的に整復された先天性股関節脱臼例の成長に 伴うSeverin 判定の推移を検討した。

(2)約半数では思春期直前に一時改善し，思春期に悪 化するパターンを示したが，整復方法により，また症 例により差異が見られた。

(3) X 線成績の推移が一定のパターンを示さないこ とから, 成長終了までの経過観察の重要性が改めて明 らかとなった。

\section{参 考 文 献}

1）池田 威, 他：いわゆる臼蓋形成不全の長期自然経過. 日整会誌, $63: S 517,1989$.

2）片田重彦, 他：RB 法後の臼蓋発育一骨成熟までの経 過一。整会誌, $62: \mathrm{S} 1225,1988$.

3）野口康男，他：保存的治療を受けた先天性股関節脱臼 の予後の推定. 日小整会誌, $1: 248-251,1991$. 